\title{
"Dar-Al-Nodveh": The First Experience of Collective Wisdom in Managing Mecca City
}

\author{
Asghar Montazerol Ghaem ${ }^{1}$, Bahman Zeinali ${ }^{1} \&$ Seyed Asghar Mahmoud Abadi ${ }^{1}$ \\ ${ }^{1}$ Department of History, University of Isfahan, Isfahan, Iran \\ Correspondence: Bahman Zeinali, Department of History, University of Isfahan. Isfahan. Iran. Tel: \\ 98-913-270-9064. E-mail: bahman.zeinali@gmail.com
}

Received: June 11, 2012 Accepted: July 17, 2012 Online Published: September 28, 2012

doi:10.5539/ach.v5n1p18

URL: http://dx.doi.org/10.5539/ach.v5n1p18

\begin{abstract}
The history of Hejaz especially in one century before Islam was affected by Quraysh tribe. All political, social and economical changes were under the control of Quraysh leaders. Qsy Ibn Kalab was the most influential leader of this tribe during history. His unique courageous deeds have change Quraysh from some dispersed tribes to a unified effective tribe. Among such acts of this leader was foundation of "Dar-Al-Nodveh" which was very significant. Dar-Al-Nodveh guaranteed the success of all acts performed in Quraysh and other tribes. Leaders of Quraysh organized their important deeds within the framework of the making opportunities resulted in expansion of this city due to decisions made by elites of the city and consequently Mecca was turned into the biggest business republic of Arabestan. Even they leaded a part of commercial market of the world. They could keep that safe and dispelled all probable dangers. The question is that the idea for formation of this government city, "Dar-Al-Nodveh", is that how came to the mind of Qsy Ibn Kalab and how much was the influence of Dar-Al-Nodveh in Mecca and how did it gave identity to the city? It seems that the international conditions of that time and personality of Qsy Ibn Kalab had very significant influence on the future of the city of Mecca. His corrective actions did much in turning Mecca to a prominent city in peninsula. The present article aimed to study general formation process of this government city with emphasis on the role of Qsy Ibn Kalab.
\end{abstract}

Keywords: Dar-Al-Nodveh, Mecca, Quraysh, Qsy Ibn Kalab, Kabe

\section{Introduction}

Regarding the point that Islam was come out of Mecca, and Prophet Mohammad (peace be upon him) leaded that big revolution as a child of Mecca, thus one of the main aspect in studying Arab society before Islam, is knowing and getting more familiar with Mecca and its residents. This provides a more exact understanding of Islam and its influence on changes happened to Arab society.

Different dimensions can be considered for studying history of Mecca, namely this city was in the center of economical interactions of that time, formation of a unified society as Quraysh in that city and its role in different political, economical, social changes was very significant in two centuries before Islam. Specifically Qsy Ibn Kalab did much in unification of Quraysh and in formation of a council as "Dar-Al-Nodveh".

This article will consider the process of changing Mecca to a "Metro pol" (free business zone); Also will consider Qsy Ibn Kalab and analyses his actions in Mecca especially his creative idea in establishing "Dar-Al-Nodveh". The extent of influence of this council will be evaluated on Quraysh and on Mecca. This is very important that how did the idea for founding such council come to Qsy's mind. Whether the environment in which he grew within Ghozae-Ghassanian province and Rome Government - had any influence on the formation of this idea or not; more importantly, Whether Dar-Al-Nodveh was council only limited to Quraysh or was the council of wealthy people of Mecca by management of Quraysh? It seems that Qsy influenced by the governing method of Ghassanian which was affected by East Rome Empire founded "Dar-Al-Nodveh". He was completely conscious about the result of having such council for improvement of the city. He tried to call on some experienced wise men from all tribes of the Mecca for consulting together and Quraysh had specific advantages in this council. 


\section{Role of Mecca in World Changes}

In middle of the fifth century, AD, there were many wars between Iran and Byzantine which finally Iran conquered Rome. Consequently commercial routes which passed through west Asia were closed. This helped Quraysh to obtain the monopoly of business of India, Abyssinia and Yemen (Balazari, 1963).Therefore Hejaz was the meeting point of those who were going to Yemen or were crossing Taif or were going to sham or East. Hejaz was located between sham and Yemen and it was located on the business road from south to north. This specific situation helped to the formation of commercial cities in this land. Merchants settled in those cities to rest. Mecca had gained prosperity because of this. Another factor which influenced growth and brightness of Mecca was its near distance to famous commercial bazars which were held in Haram months such as Akaz, Majne, Abyssinia and Zee-Majaz (Arzaghi, 1989). Mecca was located as an important center on the way between Yemen and Sham. Products of East from Forat delta, through Persian Gulf and Yemen, Egypt and Syria were come to that city. Mecca was like a bridge between wests and East, It has the situation and position that "Tedmer" Once had in the time of Parthian and Romans.

Geographical position of Mecca and independence of Quraysh brought a good opportunity for success of this city (Salem, 2007). Another factor which influenced on the process of becoming a Metropolitan was "Kabe". This city was located in the center of two courses, religious as well as economical course. In fact this city was both a religions as well as merchant, business city. These two aspects dominated this city for a long time but in 6th century this combination of religion and business got to the highest level when Qsy performed his deeds in Mecca.

\section{Qsy Ibn Kalab}

When Kalab Ibn Mareh died he left two children, Zohreh and Zeyd. Their mother was Fatima Bente Amorobne Sad Ibn Seyl (Tabari, 2004). Fatimah after death of her husband married Rabie Ibn Haram from Qzaeh tribe. Qzaeh tribe lived in an area near Sham, so Rabie went to sham and he took his wife with himself to sham, they also took Zeyd with themselves because he was a little child. Zeyd grew up in Qzaeh tribe; there they named him Qsy because he was far from his own land, Mecca (Ibn Sad, 1990). Qsy lived for many years in sham within Qzaeh tribe, when he became a strong youth he came back to Mecca and found his relatives. He married daughter of the leader of Khozaeh in Mecca. He governed Mecca at that time and was in charge of Kabe. Qsy after his death took his place and was in charge of managing Kabe.

His domination over Kabe annoyed Khozaeh tribe and they opposed him, even they announced a war against him and against these tribe members. Apparently they were angry because Qsy had become the manager of Kabe but in fact Khozaeh tribe had understood that a new power was forming in Mecca. Even before marriage to daughter of the leader of Khozaeh and becoming responsible for managing Kabe, Qsy had found especial position among Quraysh. More importantly he could gather all branches of Quraysh which were dispersed collectively in Mecca near Kabe. Quraysh was the most creditable branch of the children of Esmael who lived around Mecca in muddy houses and tents. Qsy after establishing Quraysh in Mecca divided them into some parts. He differentiated between Quraysh Zavaher and Batah (Arzaghi, 1989). The reason for this classification is not clear. But the important points is that Qsy after gathering Quraysh around Kabe and building houses for them, provided the necessary background for formation of a rule-governed society. He localized Quraysh in Mecca and managed the city based on an exact plan. He gave the responsibility of the managing the city to his son. According to this division he gave the responsibility of watering and being the leader to Abde Manaf, managing Dar-Al-Nodveh to Abdo-Al-dar and hosting Pilgrims to Abdo-Al-oza (Yaghubi, 1983).

Arzaghi wrote about this issue: "Qsy became the most Influential Person of Mecca, he was too wise, and he divided affairs of Mecca which consisted of six parts between his two sons. Abdo-Al-Dar was in charge of Kabe and managing council of Quraysh "Dar-Al-Nodveh". Responsibility for delivering water to Hojaj (pilgrims), hosting them ("Refadat"), leading and managing them ("Gheyadat") was delivered to Abde-Al-Manaf" (Arzaghi, 1989). Qsy did many great acts in Mecca. He excavated a well in Mecca, named "Ajul". He excavated another well near "Radm Ala" next to the house of Aban Ibn Osman, but this well was abandoned after a while. He is also the first person who rebuilds Kabe after "Tabo" (Ibn Darid, 1991).

Among all his actions Founding Dar-Al-Nodveh was very prominent. About his faith, Shahrestani wrote: Qsy forbids worshiping anything else rather than God which car be gods (idols)" (Shahrestani, 1985). Although any Judgment about his religion is not easy, it is clear that he tried a lot about worshiping idols, like goddess of Lat, Oza and Manat, girls of Jewish, Christian and Sami God. Traditional reports validate that Qsy and Quraysh revived unification tradition of Bible in the life of the people of Mecca. This tradition was weakened at that time 
by pagans (Holt, 2004). Therefore Quraysh respected Qsy and called him "Mojama" which means they didn't get together without his permission. They put his death date as the basis of their history (Ibn- Ishaq, 1963).

\section{Dar-Al-Nodveh: History and Its Etymology}

"Nodveh" and "Nadi" literally means assembly of the tribe and the place for their talking. Those who are related to Dar-Al-Nodveh are called "Nodveh". Dar-Al-Nodveh is a place of gathering in which there is call for getting together and talk about different affairs (Ibn Manzur, 1984). Ibn Sad wrote about the origin of this word, as this is called Dar-Al-Nodveh because Quraysh got together in any good or bad event and "Noda" is the place of gathering (Ibn Sad 1990). Arzaghi about Dar-Al-Nodveh in the history of Mecca writes: Dar-Al-Nodveh was famous as so because some people were summoned up for counseling (Arzaghi, 1989).

When Qsy succeeded in collecting Quraysh from mountains and valleys around Mecca and he could over Qzaeh by the help of Khozaeh and Kenaneh, in fact the foundation of a stable political social economical organization was established. He made the Quraysh inhabited in Mecca, execrated wells in it for providing drinking water of people and also he rebuilt the Kabe which was ruined by passage of time, then he strengthened the status of Quraysh in Mecca. Accordingly he shared different responsibilities between different tribes according to the needs of the city. For following this policy he established a center, Dar-Al-Nodveh, in Mecca. Dar-Al-Nodveh is referred to as the first house which was made in Mecca, then after its construction people built other houses around Kabe and inhabited there. Some said that Daro-Al-Ejleh which was house of Saad-Ibn-Sahm from BaniSahm tribe, was the first house built in Mecca (Hamavi, 2001).

Dr Javad-Ali rejects this view and believes that this is not the real truth and was only expressed due to tribal competitions. In fact Daro-Al-Ejleh is the second house which was built there after Dar-Al-Nodveh (Javad-Ali, 1980). On the other hand histographers have different views about whether this house was Qsy's own house or was only a building for meetings. Most histographers believe it was a center for assembly and only some of them believe that this was Qsy's personal house (Ibn-Ishaq, 1963). Building a house like that as a counseling center probably was a kind of making copy of other similar samples in Peninsula. Among Arabs of south in Sabaeeyan Kingdom building a center like that was reported. In Yemen "Beyt va kol" was considered counseling house in which leaders of Ashireh (tribe) gathered together and talk about their common Companions (Ahru) also had an assembly which was named "Mazud". Their leaders got together there in Mazud (Javad-Ali, 1980).

\section{Geographical Location and the Building Dar-Al-Nodveh}

Considering the characteristics of the buildings of peninsula especially of Hejaz it seems improbable to build house and glorious palaces like those in Yemen, Lakhmiyan or Al-Ghassan in Mecca. Therefore houses in Mecca were small consequently and Dar-Al-Nodveh was also small. Considering materials used in its construction, available materials in Mecca such as stone, clay, and wood was used in its construction. There is no report of using other materials in constructing this building and even not about Kabe. About the location of DarAl-Nodveh it is mentioned that it was built next to Kabe and one of its doors was in front of Kabe. Comparing it to the present structure of Holy mosque, the location of Dar-Al-Nodveh was in Shami porch of Holy mosque in Mecca (Ibn-Sad, 1990).

\section{Structure and Functions of Dar-Al-Nodveh}

The main purpose of Qsy Ibn Kalab by constructing Dar-Al-Nodveh was establishing a center for holding meetings, doing interactions, marriage ceremonies and solving problems. It was considered as counseling assembly of Mecca. This place had a similar function to "Forud" which was assembly center for "Yemenis". It was considered the counseling center of the city, a place for talking about war and peace. Also it must be mentioned that it was considered as a place to gain wealth among leaders of the city. Dar-Al-Nodveh was counseling center and was managed by "Malae" (Javad-Ali, 1980).

Dar-Al-Nodveh generally was a place for making decisions about major problems of Mecca. They decided how to solve and face different issues. In fact decision about critical issues was made there. "Malae" of Mecca got together there in Dar-Al-Nodveh; they were leaders, wealthy men and governors. That was not like today parliaments or assembly of leaders as they exist publically today, rather it was only a place for gathering of prominent figures. Execution of its verdicts was not obligatory and sometimes one of those big leaders preferred his own view. Gathering there needed agreement of all, and most of the time there was no general agreement. Influence of each vote was proportionate to the statue of the person and Mala usually didn't declare any view except after assessing all related aspects. They were thoughtful about the consequences of that view; they tried to prevent any kind of insecurity in the city. Sometimes leaders of a tribe had a more effective role in resolving a problem compared to Dar-Al-Nodveh, family tribal problems usually were solved within the tribe and they did 
not let it to go out the limits of the tribe. Therefore only issues which were more general were proposed in DarAl-Nodveh, problems which were related to the whole city and not specifically to a branch or tribe. Decisions about future of the city were made there (Javad-Ali, 1980).

\subsection{Political Duties}

Dar-Al-Nodveh was a counseling assembly and also was a governing center. Counsel about war and a related issue were held there (Balazari, 1988). They decided there to start a war or not (Yaghubi, 1983). If they were supposed to make peace and finish conflicts, this issue was discussed in Dar-Al-Nodveh (Ibn kasir 1997) One to three people participated from each "Batn" in discussions. During Qsy's time after counseling, finally Qsy's view was executed. Quraysh did not obviate his view and followed him as religious principal, they never rejected his view. But after him because there was no other powerful leader like him, it is not clear how they did act when there was disagreement between members of the Dar-Al-Nodveh. Doubtlessly minority numbers of members were not submissive to majority members and they acted based on their own view when there were disagreements. In fact Dar-Al-Nodveh had not execution power, and only leaded the general movement of political trend. In fact general policy of Mecca was identified there. On the other hand some other researchers proposed another view. They believe Qsy although unified disperse tribes of Quraysh and could perform corrective actions to reduce unfavorable situation which dominated Quraysh in the time of Khozaeeyan, but he never could became the absolute governor of that tribal society.

Foundation of Dar-Al-Nodveh in that city was the clearest evidence that, leadership was limited in that city, and Qsy's power consequently was also limited. Dar-Al-Nodveh was the center for talking and counseling among all tribes of Mecca like Khozaeh, which somehow was at the same level to Quraysh. Qsy had no other choice rather than accepting them, because they had governed Mecca for a long period of time. But after becoming weak and instable in Mecca and expansion of tribes of Quraysh, gradually Dar-Al-Nodveh changed into a center for gathering of leaders (Zargari Nezhad, 1990). Dar-Al-Nodveh had many different duties. Other than making decisions about wars and making peace, an agreement was also written in that place. Abdulmutallab's agreement with Khozaeh was written in there (Ibn-Sad, 1990).

\subsection{Economical Duties}

One of important decisions which were made in Dar-Al-Nodveh was economical decisions. From Qsy's era until the appearance of Islam and conquering Mecca was the golden economical age of Mecca, and this city worked as a governmental economical city. An economical decision was of great important at that time. Big commercial caravans of Quraysh in their return journey first settled in Mecca (Ibn-sad, 1990). Ibn sad considered this issue as showing respect to Qsy but in fact it was more deeply important. Probably accounting the first capital and accounting final profit was done in Dar-Al-Nodveh. Hashem-Ibn-Abdo-Al-Manaf kept in Dar-Al-Nodveh whatever he took from people for hosting pilgrims (Hajiyan) (Ibn-Abel Hadid, 1964) Also in Dark ages (Ignorance Age) making decision about properties which were brought by pilgrims for idols was held in Dar-AlNodveh. AbuSofyan saved a Caravan of merchandise which belonged to the people of Mecca from Muslims. He kept those merchandise in Dar-Al-Nodveh and he could satisfy the owners of that merchandise to spend a part of that for equipping the army against Prophet Mohammad (Majlesi, 1980)

\subsection{Social and Cultural Duties}

Dar-Al-Nodveh was like a club in which meetings of Quraysh was held (Ibn Asir, 1991). It seems that the cultural role of Dar-Al-Nodveh was more prominent than its other roles. One of the most important cultural, social decisions was about puberty of girls. When girls reached the puberty age, came to Dar-Al-Nodveh, one of the children of Abde Manaf teared her dress and gave her a new one (Arzaghi, 1989-Vaghedi, 1986), because of this Amer Ibn Hashem Ibn Abde Manaf who did this ceremony was named "Mohiz" (Javad-Ali 1980).This ceremony was a kind of declaration that, the girl is ready for getting married and if there are any suitable people, elderly people of the tribe would announce. Official ceremony of marriage was also held in Dar-Al-Nodveh. Even girls put on marriage dress there (Ibn-Sad, 1990). Circumcision of boys was performed there (Yaghubi, 1983). Therefore not only political issues but also all cultural social ceremonies were performed in Dar-AlNodveh. Actually it was the center for consultation thinking and talking.

\subsection{Membership Conditions}

About age conditions for being a member of Dar-Al-Nodveh two views exist: some sources have talked about age 40 as the membership age (Azraghi, 1989). But on the other hand it must be mentioned that generally leaders of tribes were gathered there and age limit was not set for them, rather the position of people was important (Ebrahim Hasan, 1977). Even though histographers emphasized on the age limit of membership but there are 
some younger people were participating in their meetings. For instance Hakim Ibn Hazm entered Dar-AlNodveh when he was 15 and even he had right to vote or Abujahl when was under 30 became member of DarAl-Nodveh (Ibn Abe-Al-Hadid 1964).Thus it can be concluded that Dar-Al-Nodveh was assembly center of Quraysh where they counseled. Great wealthy men gathered together there, and it seems that a criterion for selection of them was based on wealth and the services which they delivered to the Quraysh society. Specifically they were leaders of internal main tribes of Mecca especially Batah (Shoghi, 1985).

\subsection{Directorship of Dar-Al-Nodveh}

Directorship of Dar-Al-Nodveh was inherited to Abdo-Al-dar and its directorship was changed within the AbdoAl-dar family inheritably. When Qsy became old, he appointed his older son as director of Kabe. His son was responsible to manage Kabe and take care of all pilgrims who came to Mecca. Qsy in fact wanted to support Abdo-Al-dar who was weaker than his brothers (Ibn sad, 1990).

Yaghubi does not approve this issue and writes: Qsy gave responsibility of Seghayat (giving water to pilgrims), "Refadeh" and "Gheyadat" to Abde Manaf who was more aware of political issues and only gave the responsibility of "Sedanat", "Hejabat" and Dar-Al-Nodveh to Abdo-Al-dar. He also shared these posts to other four brothers (Yaghubi, 1983). Generally managing Dar-Al-Nodveh was Malae responsibilities that were like members of Sheikhs Assembly (elderly assembly). These were elderly members of tribes and those who had right to vote and gathered to solve problems (Javad-Ali, 1980).

\subsection{Legal Status}

This center was not like parliament or house council; rather it was a place in which when it was necessary, leaders got together. Decision had no execution force but all decisions were made within Dar-Al-Nodveh limits. About status of Dar-Al-Nodveh, Ghotbo-Al-Din Nahrovali wrote: "This house was palace for counsel about war or peace issues, it was the center of government which was leaded by elders of tribes. It was like assembly of wealthy people, and it was similar to Athens church and senate of Rome" (Nahrovali, 1857).

On the other hand some scholars believe that Dar-Al-Nodveh had execution power and believes that its decision had to be performed legally. They believe that Qsy had established Dar-Al-Nodveh for decision making about very important political issues of tribes, and so it was an effective step toward organizing Mecca and dominating order and law in the city (Barzegar, 2006). Quraysh didn't perform any law except that it was proposed and passed in Dar-Al-Nodveh. Thus Dar-Al-Nodveh was more similar to senate in which there discussions about war, peace, agreements, contractions, preparing Caravans etc were done (Saleh, 2005). It seems that in spite of lack of execution power of Dar-Al-Nodveh and so people were not obliged according to its decisions, but its status and its members were so prominent that its decisions were performed without showing any disagreement.

\section{Conclusion}

The history of Mecca from fifth to seventh century, AD, experienced many ups and downs. This holly city is supposed to be built by Ebrahim and Islam considered it as the Gheble (Mecca) of Muslims. Within two centuries before Mohammad (peace be upon him) Mecca came out of solitary conditions which were the result of weather conditions of Hejaz, and it became active in the field of politics and economy of that time. This new situation was the result of two internal and external factors, within changes inside and outside of that area. Wars between two big powers of that time Iran and Rome- for taking control over commercial cities of north and south resulted in destruction of those centers and consequently Mecca commercially as well as socially prospered and expanded, therefore it changed into a governmental market.

Considering internal context of Mecca it also experienced many critical changes. Qsy Ibn Kalab after a long time that he was far away from his home town, Mecca, returned to his tribe with all experiences that he had obtained from Ghozae tribe in Sham. He made Quraysh the governing tribe to Mecca. Quraysh was the most authoritative tribe in Mecca from the descendents of Ismail. Their victory over Khozaeh and other tribes in Mecca provided the opportunity for Mecca to enter the global society and even take the control of a large part of the commercial market of that time. It played a significant role in the world at that time. One of reasons of this success was leadership of Qsy Ibn Kalab. He is one of the most famous historical figures. Quraysh took control of Mecca by Qsy's leadership. He expanded Mecca in sixth century and it became the biggest commercial republic of Peninsula. Qsy's personality was one of the most important factors which influenced the success of Mecca. All his acts especially foundation of Dar-Al-Nodveh was very significant.

Education of Qsy Ibn Kalab in Qzaeh tribe in Sham which was influenced by Roman as well as Constantinople government caused to make a unified social organization with participation of all wealthy People of Mecca with prominence of Quraysh tribe. He founded a consulting center for great leaders in order to strengthen the basis of 
this newly founded system, which was named Dar-Al-Nodveh. Qsy By cooperating with other head figures of Mecca empowered their new city and continued their existence. Economical growth of Mecca in that era shows that measures of Qsy has changed the history of Mecca. Therefore all leaders of Mecca supported decisions taken in Dar-Al-Nodveh. Important point is that under leadership of Qsy little by little his children took control of Mecca and extended their power over Mecca. This city became so strong that even after Islam it was still a prominent city. The center which was built by Qsy by help of other wealthy and great men of Mecca was changed into a great center for dominance of Quraysh not only in Mecca but also in most parts of Arabestan.

\section{References}

Abelhadid, A. H. (1964). Explanation of Nahjol balaghe. Egypt, Gahereh: Dare Ehya Alkotob Alarabiyeh.

Arzaghi, A. (1989). News of Mecca. Iran, Tehran: Bonyad publication.

Ayati, M. E. (1971). The History of the Profit of Islam. Tehran, Iran: Tehran University Publication.

Balazari, A. J. (1987). Ansab Alashraf. Beirut, Lebanon: Dar Almaref.

Balazari, A. J. (1988). Fotooh- Al-Boldan. Iran, Tehran: Nogreh Publication.

Barzegar, I. S. (2006). Value system of Mecca in advent of Islam, Islam History.

Ebrahim, H. E. (1977). Political history of Islam. Tehran, Iran: Javidan Publications.

Holt, P. M. (2004). Islamic History. Iran, Tehran: Beyn Al-Melal Publication.

Homavi, Y. (2001). Mojam Alboaldan. Iran, Tehran: Cultural heritage Publications.

Iben, H. A. (1963). Sire Alnabi. Egypt, Gahereh: Matbeye Madani.

Iben, S. M. S. (1990). Al Tabghat Al Kobra. Beirut, Lebanon: Dar Al Kotobeh Ahelmiyeh.

Ibn, A. E. (1991). Iran History. Tehran: Asatir Publication.

Ibn, D. A. M. (1991). Aleshtegag. Beirut, Lebanon: Dar Alj IL.

Ibn, E. A. A. M. (1963). Alsireh Alnabi, A research. Beirut, Lebanon: Al matbae Almadani.

Ibn, K. A. H. (1997). Albeady VA Alnehaye. Beirut, Lebanon: Maktab-Al-Maref.

Ibn, M. (1984). Lesan Alarab. Iran, Qom: Adab Alhozeh Publication.

Javad, A. (1980). Almofasal about History before Arabs. Beirut, Lebanon: Dar Alelm malaeen.

Majlesi, M. M. B. (1980). Bahar Al-Anvar (Vol. 18). Iran, Tehran: Islamic Publication.

Nahrovali, G. A. (1857). Ketab Aalam. Westfeld: Lybizik.

Saleh, A. A. (2005). Ancient Arab in the beginning of Prophecy. Iran,Tehran: Beynolmelal Publication.

Salem, A. (2007). History of Arabs before Islam. Iran, Tehran: Scientific and cultural Publications.

Shahrestani, A. K. (1985). Almelal VA Alnehal. Iran, Qom: Manchuria Alrazi.

Shoghi, Z. (1985). Literal history of Arabs in Ignorance Stage "Alasr Aljaheli”. Iran, Tehran: Amirkabir publication.

Tabari, J. M. (2004). Tabari History. Iran, Tehran: Bonyadeh farhang Publication.

Vaghedi, M. S. (1986). Tabaghat. Iran, Tehran: Nou Publication.

Yaghubi, A. Y. (1983). Yaghubi History. Iran, Tehran: Cultural Scientific Publication.

Zargari, N. G. H. (1999). History of early stages of Islam. Iran, Tehran: Samt Publication. 